Bbывод: Исходя из проведенного анализа можно сделать вывод о том, что существует множество моделей принятия управленческих решений однако, следует отметить, что для каждого отдельно взятого предприятия необходимо выбрать свою, особенную модель и попытаться адаптировать ее к внешним и внутренним условиям окружающей среды.

Для этого, необходимо выработать такую стратегическую политику предприятия, которая была бы направлена на постоянное улучшение не только его экономического положения, но и психологического климата в коллективе.

\section{ПЕРЕЧЕНЬ ИСПОЛЬЗОВАННОЙ ЛИТЕРАТУРЫ}

1 Дикань, В.Л. Економічна безпека підприємства [Текст]: навч. посібник / В.Л. Дикань, І.В. Воловельська, О.В. Маковоз. - Х.: УкрГАЖТ, 2011. - 243 c.

2 Дикань, В.Л. Управління бізнесом [Текст]: підручник / Дикань, В.Л., ПанченкоС.В., Маслова В.О., Воловельська I.В.- Х.: УкрДАЗТ, 2017. $315 \mathrm{c}$.

3 Злобина Н.В.. Управленческие решения : учебное пособие / Н.В. Злобина. - Тамбов : Изд-во Тамб. гос. техн. ун-та. 80 c. -. 2007

4 Наиболее распространенные модели процесса принятия управленческихрешений. https://helpiks.org/9-6784.html

5 Машина Н. I. Економічний ризик та методи його вимірювання [Текст]:навч. посібник/Н. І. Машина. - К.: Центр навчальної літератури, 2013. - 188 с.

DOI $10.18664 / 338.47: 338.45 . v 0 i 64.149529$

УДК 339.138

\title{
ОСНОВНІ ПІДХОДИ ДО РОЗРОБКИ МАРКЕТИНГОВОЇ СТРАТЕГІЇ ПІДПРИЕМСТВА
}

\author{
Маслова В.О., к.е.н., доцент, \\ Сапієнко І.В., магістр (УкрДУЗТ)
}

У статті розглянуті основні підходи до розробки маркетингової стратегії підприємства. Результатом використання клієнтоорієнтованого підходу є розробка маркетингової стратегї, спрямованої на максимальне задоволення потреб $і$ бажань споживача. Результатом використання конкурентоорієнтованого підходу є розробка маркетингової стратегії, спрямованої на створення продукції, щуо відрізняється від продукиї конкурента, і формування попиту у споживачів на таку продукцію. Визначено, що ефективність використання того чи іншого підходу до розробки маркетингової стратегії підприємства залежить від масштабів його діяльності $i$ конкурентної позииї в галузі.

Ключові слова: маркетингова діяльність, маркетингова стратегія, поведінка споживачів, поведінка конкурентів. 


\title{
ОСНОВНЫЕ ПОДХОДЫ К РАЗРАБОТКЕ МАРКЕТИНГОВОЙ СТРАТЕГИИ ПРЕДПРИЯТИЯ
}

\author{
Маслова В.А., к.э.н., доцент, \\ Сапиенко И.В., магистр (УкрГУЖТ)
}

B cтатье рассмотрены основные подходыл $\kappa$ разработке маркетинговой стратегии предприятия. Результатом использования клиентоориентированного подхода является разработка маркетинговой стратегии, направленной на максимальное удовлетворение потребностей и желаний потребителя. Результатом использования конкурентоориентированного подхода является разработка маркетинговой стратегии, направленной на создание продукции, отличающейся от продукиии конкурента, и формирование спроса у потребителей на такую продукцию. Определено, что эффективность использования того или иного подхода к разработке маркетинговой стратегии предприятия зависит от масштабов его деятельности и конкурентной позищии в отрасли.

Ключевые слова: маркетинговая деятельность, маркетинговая стратегия, поведение потребителей, поведение конкурентов.

\section{MAIN APPROACHES TO DEVELOPMENT OF MARKETING STRATEGY OF THE ENTERPRISE}

\author{
Maslova V.O., PhD Econ., associate professor, \\ Sapienko I.V., master (USURT)
}

In article the main approaches to development of the marketing business strategy of the enterprise are considered. The first approach is guided by behavior of the consumer (client), development of the marketing strategy directed to the maximum satisfaction of requirements and desires of the consumer is result of use of such approach. The second approach is guided by behavior of the competitor, development of the marketing strategy directed to creation of production different from production of the competitor, and formation of demand at consumers for such production is result of such approach.

It is defined that the main destination of marketing in general and marketing strategy in particular is increase in sales volumes of production of the enterprise and, respectively, income for rather long period. In this regard, it is investigated that the efficiency of use of this or that approach to development of marketing strategy of the enterprise will depend on scales of activity of the enterprise and its competitive position in branch. So for achievement of a main objective of marketing activity large and average the enterprises it is more preferable to be guided by behavior of competitors, small - by behavior of consumers. As for a competitive position in branch, for leaders, applicants and followers application of the approach focused on competitors is characteristic of beginners - the approach focused on the consumer.

Keywords: marketing activity, marketing strategy, behavior of consumers, behavior of competitors.

Постановка проблеми. В умовах сучасного бізнесу маркетинг як поняття варто розглядати у трьох основних аспектах: як економічний процес, як

філософію бізнесу та як функцію управління. Маркетинг як економічний процес являє собою сукупність дій із забезпечення контакту між виробником та

Вісник економіки транспорту і промисловості № 64, 2018 
споживачем, підвищення ефективності ринкового обміну між ними та усунення завдяки цьому невідповідності між пропозицією та попитом. Маркетинг як філософія бізнесу може бути розглянутий в контексті образу мислення, при якому динамічному збуту продукції та послуг підприємства підпорядковується прийняття будь-яких управлінських рішень. Нарешті, маркетинг як функція управління визначає ринкову (ділову) та виробничу стратегію підприємства. В тім, в якому б аспекті не розглядалося це поняття, основне призначення маркетингу - збільшення доходів підприємства за рахунок забезпечення зростання обсягу продажів продукції, робіт, послуг підприємства у довгостроковій перспективі.

Роль маркетингу відповідно 3 його призначенням особливо актуальна в умовах нестабільної економічної ситуації, невизначеності ринкового середовища, оскільки потреби суспільства майже безмежні, але можливості або ресурси для їх задоволення обмеженні. За таких умов найбільш доцільним $є$ застосування стратегічного підходу до ведення маркетингової діяльності, що полягає у розробці та реалізації маркетингових стратегій.

Аналіз останніх досліджень $\boldsymbol{i}$ публікацій показав, що, зважаючи на зростання ролі маркетингу в сучасних умовах господарювання, питанням підвищення ефективності маркетингової діяльності підприємств приділяється велика увага як науковців, так і фахівців 3 питань маркетингу в Україні та світі. Серед досліджень за останні роки можна виділити праці Котлера Ф., Амстронга Г., Вонг В., Сондерса Д. [1], Траута Д., Райса Е. [2], Воловельскої В.Л., Маслової В.О. [3], Петруня Ю.С. [4] та інших вчених та фахівців, в яких розглядаються поняття, цілі, принципи, методи, підходи маркетингу тощо, наголошується на зростаючій ролі маркетингової діяльності у забезпеченні конкурентоспроможності підприємств в сучасних умовах ведення бізнесу. Питання застосування стратегічного підходу до управління у тому числі й маркетинговою діяльністю досліджувалися у працях таких вчених, як Дж. О’Шонесси [5], Траута Д., Райса Е. [2], Диканя В.Л. [6,7], Панченко С.В., Воловельської І.В., Маслової В.О. [7], Войтович С.Я. [8], Герасименко В.М. [9], Черкашеної М.В. [10] та інших вчених i фахівців, де розглядалися питання підвищення ефективності розробки та реалізації маркетингової стратегії, її місця та ролі в системі стратегічного планування діяльності підприємства.

Виділення невирімених частин загальної проблеми. У той же час у зазначених роботах питання застосування основних підходів до формування маркетингової стратегії відповідно до конкурентної позиції підприємства на ринку, розглядаються не достатньо.

Метою cmammi $\epsilon$ визначення основних підходів до розробки, вибору та реалізації маркетингової стратегії підприємства, їх особливостей та обгрунтування доцільності їх застосування у відповідності до конкурентної позиції підприємства на ринку.

Виклад основного матеріалу. Маркетингова стратегія являє собою концепцію діяльності (програму дій) підприємства, спрямовану на збільшення обсягу продажів та доходів у довгостроковому періоді за умови раціонального використання наявних для цього ресурсів підприємства.

В структурі функціональних стратегій на сьогоднішній день маркетинговій стратегії відводиться першочергове значення, оскільки, як відомо, будь-яке підприємство створюється з метою отримання прибутку за рахунок задоволення ринкового попиту. Всі інші функціональні стратегії (виробнича, фінансова, інвестиційна, інноваційна тощо) розроблюються на основі маркетингової стратегії. 
При цьому маркетингова стратегія завжди повинна відповідати змінам у поведінці клієнтів та конкурентів, без цього підприємству не вдасться зайняти вигідної позиції на ринку.

У зв'язку з цим можна виділити два основних поведінкових підходи до формування маркетингової стратегії підприємства: 1) клієнтоорієнтований підхід; 2) конкурентоорієнтований підхід.

Клієнтоорієнтований підхід спрямований, перш за все, на дослідження поведінки споживачів, визначення факторів, що спонукають споживачів до зміни своєї поведінки, аналізу їхніх потреб, рівню задоволення цих потреб та орієнтацію маркетингової політики та стратегії діяльності підприємства саме на задоволення існуючих потреб споживача, клієнта.

Це загальноприйнятий підхід до розробки та реалізації маркетингової стратегії, він відповідає класичному визначенню маркетингу, за яким мета маркетингу полягає у задоволенні потреб споживачів.

В основі цього підходу лежить ієрархія потреб Маслоу та визначення потреби як того, що необхідно людині для існування і оптимального функціонування. Нагадаємо, що до них відносяться: фізіологічні потреби (голод, спрага, холод); потреби самозбереження (безпека); соціальні потреби (любов); потреби в повазі (статус); потреби в самоствердженні (самореалізація) [3].

При цьому під поведінкою споживача розуміється когнітивна (пізнавальна), емоційна i фізична активність, яка проявляється людьми (споживачами) при виборі, оплаті, використання товарів i послуг, та припинення такої при задоволенні людських потреб і бажань [3].

Більшість науковців та фахівців 3 питань маркетингу схиляються до думки, що використання саме цього підходу дозволить досягти підприємству конкурентних переваг на ринку.
Конкурентоорієнтований підхід полягає у тому, що підприємство при формуванні та реалізації маркетингової стратегії досліджує поведінку конкурентів та фактори, що спонукають конкурентів до зміни своєї поведінки на ринку.

Під поведінкою конкурента будемо розуміти ринкову активність товаровиробника, спрямовану на розширення або збереження обсягів власної діяльності за рахунок зменшення ринкової долі іншого товаровиробника суб'єкта цього ринку або ринку взаємозамінюваного товару.

Можна виділити три основні типи поведінки конкурентів: креативний, пристосовницький, забезпечуючий [11]. При креативній поведінці підприємство здійснює заходи, спрямовані на створення нових елементів відносин, які забезпечували 6 перевагу над конкурентами. Наприклад, розробка i впровадження нової продукції, нові технології, нових способів організації виробництва тощо. Головна ознака креативної поведінки - це прагнення до зміни існуючої структури попиту та пропозиції. Така поведінка притаманна лідерам галузі із значним інноваційноінвестиційним потенціалом.

Пристосовницький тип поведінки полягає у врахуванні інноваційних змін в виробництві у конкурентів і заходи попереджувальних дій конкурентів. Пристосовницька поведінка застосовується тоді, коли підприємство не зовсім впевнено в своїх інноваційних можливостях і тому прагне до копіювання, можливо в більш короткі терміни досягнення конкурентів, у тому числі шляхом промислового шпигунства. Такий тип поведінки найбільш притаманний претендентам на лідерство.

Забезпечуюча поведінка заснована на прагненні підприємства до збереження на тривалу перспективу свого становища на ринку за рахунок підвищення якості товару, розширення асортименту, надання додаткових послуг. Цей тип поведінки 
застосовується тоді, коли підприємство не має можливості суттєво змінити виробничу i збутову програми i має слабкий інноваційний потенціал. Більше за інших до такого типу поведінки схильні підприємства-послідовники.

У будь-якому разі при використанні конкурентоорієнтованого підходу для розробки маркетингової стратегії підприємство спрямовує свої зусилля на аналіз дій конкурентів та визначення їх слабких місць у продуктових стратегіях. Головна мета такого підходу - обійти конкурента, наприклад, за ціною, якістю або асортиментом продукції, швидкістю подачі товару-новинки на ринок, а потім сформувати у споживача уявлення, що саме ця продукція задовольнить якусь його потребу, активно доводячи інформацію до потенційного клієнта про наявність такого товару та іiі унікальні відмінності від аналогічної продукції інших продавців на ринку.

Засновниками цього підходу у маркетингу можна вважати Джека Траута та Ела Райса [2]. Основна теза їхньої праці полягає у тому, що «справжня природа маркетингу на сьогодні $\epsilon$ конфлікт між корпораціями, а не задоволення людських потреб». I справді, розвиток науковотехнічного прогресу, наприклад, у сфері телефонного зв'язку (стаціонарний провідний телефон - радіотелефон сотовий телефон - нарешті, смартфон) відбувся завдяки інноваційноінвестиційній діяльності підприємств цієї сфери бізнесу та рекламі (доведеної до потенційного споживача інформації про наявність) отриманих результатів. Навряд чи власник стаціонарного телефону взагалі мав реальну потребу у безпровідному зв'язку, так само як і власник сотового телефону вимагав задовольнити потребу у тому, щоб мати мінікомпьютер завжди під рукою. Тобто відбулося формування попиту на ці види продукції, а не задоволення раніше існуючих потреб.

Тут треба звернути увагу на те, що автори говорять не про будь-яке підприємство, а саме про корпорації. За законодавством України корпорацією визнається договірне об'єднання, створене на основі поєднання виробничих, наукових і комерційних інтересів підприємств, що об'єдналися, з делегуванням ними окремих повноважень централізованого регулювання діяльності кожного 3 учасників органам управління корпорації. Тобто маються на увазі достатньо великі за масштабами діяльності суб'єкти господарювання 3 масовим, крупносерійним або серійним виробництвом продукції. Такі підприємства мають можливість активно вести інноваційно-інвестиційну діяльність відносно розробки нових видів продукції, а також діяльність 3 просування своїх нових товарів на ринок.

Безсумнівно, певні побажання своїх споживачів відносно виробництва необхідної для задоволення їхніх потреб продукції виконуватися будуть, але це стосуватиметься удосконалення базової стандартної продукції, випуском якої займаються й фірми-конкуренти. Саме напрямком удосконалення такої базової стандартної моделі буде відрізнятися продукція конкуруючих корпорацій. Крім того, великі за обсягами виробництва i реалізації продукції підприємства прагнуть до максимального використання ефекту від масштабу діяльності, зниження собівартості продукції, що можна досягти за рахунок стандартизації та уніфікації всіх складових виробництва (обладнання, ресурсів, бізнес-процесів, самої продукції тощо). Тому розраховувати на те, що великі підприємства будуть займатися задоволенням унікальних потреб одного або групи споживачів, не приходиться.

Крім того, підприємство, розробляючи свою продуктову стратегію на базі лише визначення потреб споживачів, отримує в результаті ряд продуктів (товарів), ідентичних тим, що випускаються підприємствамиконкурентами, які також витрачають колосальні кошти на дослідження того ж 
самого ринку та визначення тих же самих потреб. Тобто задоволення попиту відбувається, але суттєве збільшення обсягів продажів та зростання доходів від цих продажів малоймовірно. Основне призначення маркетингу у цьому випадку не буде досягнуто.

Таким чином, щоб стати переможцем у конкурентній боротьбі за обсяги продажів підприємства, перш за все, крупного бізнесу повинні орієнтуватися на конкурентів 3 метою визначення найбільш уразливих місць у їхніх позиціях та «влаштовувати маркетингові атаки, спрямовані саме туди $[2] »$.

Саме тому для великих за масштабами діяльності підприємств найбільш доцільним буде застосування конкурентоорієнтованого підходу до визначення маркетингової стратегії та досягнення конкурентних переваг на ринку.

Інша справа, підприємства індивідуального та дрібносерійного виробництва. Їх діяльність характеризується високою якістю та вартістю продукції саме через необхідність максимального задоволення потреб та виконання вимог споживача. Для таких підприємств застосування клієнтоорієнтованого підходу до розробки та реалізації маркетингової стратегії $\epsilon$ найбільш доцільним та може забезпечити певні конкурентні переваги на ринку.

Також клієнтоорієнтований підхід може бути вдало застосований підприємствами-новачками, для яких характерним $є$ пошук ринкової ніші, яка повинна бути досить прибутковою, мати потенціал зростання і не привертати увагу великих конкурентів.

Висновок. Таким чином, при розробці маркетингової стратегії підприємства, головним призначенням якої $\epsilon$ забезпечення зростання обсягів продажів та доходів від них, може застосовуватися як клієнтоорієнтований підхід (забезпечення потреб та бажань споживача), так і конкурентоорієнтований підхід (формування потреб і бажань споживача). Ефективність застосування того чи іншого підходу у маркетинговій діяльності визначається переважно масштабами діяльності підприємства в цілому (великі та середні підприємства орієнтуються переважно на поведінку конкурентів, малі - на поведінку споживачів) та конкурентною позицією підприємства у галузі (для лідерів галузі, претендентів та послідовників характерно застосування конкурентоорієнтованого підходу, для новачків клієтоорієнтованого підходу).

\section{ПЕРЕЛІК ВИКОРИСТАНИХ ДЖЕРЕЛ}

1 Котлер Ф. Основы маркетинга (5-е европейское издание) / Ф.Котлер, В.Вонг, Д.Сондерс, Г.Армстронг. - М.: ИД «Вильямс», 2012. - 752 с.

2 Траут Д. Маркетинговые войны / Джек Траут, Эл Райс. - С-Пб: Питер, 2018. $-288 \mathrm{c}$.

3 Воловельская И.В. Исследование факторов, влияющих на поведение потребителей в современных условиях / И.В.Воловельская, В.А.Маслова // Вісник економіки транспорту і промисловості. 2018. - №61. - C.117-123.

4 Петруня Ю. С. Маркетинг: навч. посіб. / Ю.С.Петруня, В.Ю.Петруня; 3-тє вид., переробл. i доповн. Дніпропетровськ: Університет митної справи та фінансів, 2016. - 362 с.

5 О’Шонесси Дж. Конкурентный маркетинг: стратегический подход / Дж. О’Шонесси; пер. с англ. под ред. Д.О. Ямпольской. - СПб: Питер, 2001 - 864 с.

6 Дикань В. Л. Стратегічне управління: навч. посіб. / В. Л. Дикань, В.О. Зубенко, О.В. Маковоз, І. В. Токмакова, О. В. Шраменко - К.: Центр учбової літератури, 2013. - 272 с.

7 Дикань В.Л. Управління бізнесом: підручник / В.Л. Дикань, С.В. Панченко, І.В. Воловельська, В.О. Маслова. - Х.: УкрДАЗТ, 2017. - 315 с. 
8 Войнович С.Я. Сутність і зміст 2017. - № 58. - С. 143-152. поняття «маркетингова стратегія» / С.Я. Войнович, Потапюк І.П. // Вісник ПолтНТУ:Економіка і регіон. - 2011. №4(31). - C.77-81.

9 Герасименко В.М. Підвищення конкурентоспроможності продукції підприємства за рахунок маркетингової стратегії / В.М.Герасименко. // Вісник економіки транспорту і промисловості. -

10 Черкашина М.В. Стратегічне управління процесом забезпечення ефективності комерційної діяльності підприємства / М.В.Черкашина. // Вісник економіки транспорту і промисловості. 2018. - № 62. - С. 355-361.

11 Типы конкурентного поведения [Электронный ресурс]. - Режим доступа: http://rgrtu-640.ru/predpr/predpr16.html

DOI 10.18664/338.47:338.45.v0i64.149562

УДК 65.011.2:338.45(477)

\title{
СТРАТЕГІЧНЕ УПРАВЛІННЯ РОЗВИТКОМ ПІДПРИЕМСТВ В УМОВАХ ЦИФРОВІЗАЦІї ЕКОНОМІКИ
}

\author{
Токмакова I.В., д.е.н, професор, \\ Шатохіна Д.А., махістр, \\ Мельник С.В., магістр (УкрДУЗТ)
}

В статті досліджено характеристики иифрової економіки як сучасного тредну суспільного розвитку. Визначено, щуо иифрровізація супроводжується трансформацією господарських прочесів: від роботизачії виробництва благ (товарів $і$ послуг) масового споживання до нових виробництв зі створення благ $з$ індивідуальними характеристиками для кожного споживача. 3'ясовано, щзо компанії з найбільшою капіталізачією у світі вже давно перейшли на цииррову економіку, що спричинило значне підвищення ефективності їхньої роботи. Проаналізовано передумови цчифровізації економіки Украӥни $і$ зроблено висновок, що нама країна явно відстає за низкою показників від країн-лідерів в сфері інформатизачії економічних прочесів, при иьому цифрова трансформація має стати стратегічним орієнтиром розвитку, так як дає шанс Україні здійснити технологічний прорив. Грунтуючись на тому, щуо підприємства $\epsilon$ ядром цифррового переходу економіки країни розкрито стратегічні аспекти управління украӥнськими підприємствами на засадах циирровізації, у тому числі визначені альтернативні стратегії, цілі та ключові напрямки цифрової трансформації.

Ключові слова: цифрова економіка, підприємство, стратегічне управління, розвиток, інформаційно-комунікаційні технології.

(C) Токмакова I.B., 